\title{
Rhodomyrtone from Rhodomyrtus tomentosa (Aiton) Hassk. as a Natural Antibiotic for Staphylococcal Cutaneous Infections
}

\section{Jongkon Saising, ${ }^{a}$ Asadhawut Hiranrat, ${ }^{b}$ Wilawan Mahabusarakam, ${ }^{b}$ Metta Ongsakul, ${ }^{a}$ and Supayang Piyawan Voravuthikunchai ${ }^{*, a, c}$}

\author{
${ }^{a}$ Department of Microbiology, ${ }^{b}$ Department of Chemistry, and \\ ${ }^{c}$ Natural Products Research Center, Faculty of Science, Prince \\ of Songkla University, Hat Yai, Songkhla 90112, Thailand
}

(Received May 31, 2008; Accepted August 4, 2008)

The ethanol extract of Rhodomyrtus tomentosa (Aiton) Hassk. (R. tomentosa) was determined for its antibacterial activity on staphylococci isolated from acne lesions. Antibiotic susceptibility patterns of the isolates were performed. Preliminary screening of the antibacterial property of the extract using disk diffusion method demonstrated pronounced antibacterial activity of the extract on all tested isolates. The average inhibition zones of 64 coagulase-positive and 85 coagulase-negative isolates were $12 \mathrm{~mm}$ and $14 \mathrm{~mm}$, respectively. Minimal inhibitory concentration (MIC) was determined by broth microdilution method. The $\mathrm{MIC}_{50}$ and $\mathrm{MIC}_{90}$ ranged from 64$512 \mu \mathrm{g} / \mathrm{ml}$. Time-kill curves were assessed at $0.5 \mathrm{MIC}$, MIC, 2 MIC, and 4 MIC by counting viable bacterial cells after time intervals. At $4 \mathrm{MIC}$, the level of treated staphylococci declined by at least $3 \log$ fold within 6-8 hr. Rhodomyrtone, a pure compound in acylphloroglucinol class, isolated from this plant species was very effective against Staphylococcus aureus (S. aureus) ATCC 25923 with the MIC value at $0.5 \mu \mathrm{g} / \mathrm{ml}$ which is very closed to that of vancomycin. This finding challenges the use of rhodomyrtone as an alternative agent for staphylococcal cutaneous infections.

Key words — staphylococci, rhodomyrtone, Rhodomyrtus tomentosa, antibacterial activity, acnes, time-kill study

\footnotetext{
${ }^{*}$ To whom correspondence should be addressed: Natural Products Research Center and Department of Microbiology, Faculty of Science, Prince of Songkla University, Hat Yai, Songkhla 90112, Thailand. Tel. \& Fax: +66-7444-6661; E-mail: supayang.v@psu.ac.th
}

\section{INTRODUCTION}

Staphylococci colonize skin epithelial surfaces in the majority of humans. The infections involve a variety of cutaneous and systemic infections including impetigo, furuncle, subcutaneous abscess, staphylococcal scalded skin syndrome, toxic shock syndrome and neonatal toxic shock syndrome likeexanthematous disease. ${ }^{1)}$ Staphylococci are one of the microorganisms commonly isolated from acne lesions. ${ }^{2)}$ The presence of oleic acid released by the hydrolysis of serum lipids by staphylococcal lipase could be pathologically important. ${ }^{3)}$ The pathological significance of lipase from staphylococci has been suggested that they influence the development of acne. ${ }^{4)}$ The production of lipolytic enzymes by Staphylococcus epidermidis (S. epidermidis) and possibly Staphylococcus aureus (S . aureus) may be an indicative that lipase is important to the organisms for their colonization and growth within the lipid-rich environment of the skin. ${ }^{5)}$

Acne vulgaris is a skin disease that affects young people worldwide. Although acne is not a serious infective disease, young people presenting with acne are at increased risk of depression, anxiety, and suicide attempts. ${ }^{6}$ ) Moreover, acne is a substantial problem, which causes patients to initiate millions of visits per year to physicians with a total cost of acne likely to exceed $\$ 1$ billion. ${ }^{7)}$

Antibiotics have successfully been applied for many decades to suppress infectious organisms. However, the widespread use of antibiotics has raised fears that increased numbers of bacteria will become resistant, thereby diminishing the overall ability of antibiotics to control the infection. ${ }^{8}$ ) There have been many reports about staphylococcal resistance to the majority of existing antibiotics. ${ }^{9-11)}$ Various plant extracts have been vigorously studied in our laboratory for an alternative treatment. ${ }^{12)}$

The Myrtaceae is a significant family in herbal medicine. Antibacterial activities of some members of this family have been well-documented. Eucalyptus globulus had antibacterial activity against $S$. aureus, Streptococcus pyogenes (S. pyogenes), Streptococcus pneumoniae, and Haemophilus influenzae. ${ }^{13)}$ The antibacterial activity of Melaleuca alternifolia has been reported by many researchers. Terpinen-4-ol and $\alpha$-terpineol were demonstrated to reduce the viability of $S$. aureus. ${ }^{14)}$ Other effective plants in this family against $S$. aureus include Syzygium jambos, ${ }^{15)}$ Syzgyium aromaticum, ${ }^{16}$ ) Eucalyptus camaldulensis, ${ }^{17)}$ and Callistemon 
rigidus. ${ }^{18)}$ In contrast, there have been very few reports on antibacterial activity of Rhodomyrtus tomentosa (Aiton) Hassk. (R. tomentosa) ${ }^{19)}$ Limited work from our group has been previously documented. ${ }^{20)}$ Its activities against Gram-positive bacteria including Bacillus cereus, Enterococcus faecalis, Listeria monocytogenes, $S$. aureus and $S$. pyogenes were remarkable. As a part of research workers in the field of complimentary medicine, this investigation focus on the antibacterial activities of this plant against staphylococci isolated from acne lesions in order to search for a new effective natural antibiotic for the infection.

\section{MATERIALS AND METHODS}

\section{Isolation and Identification of Staphylococci -} Specimens were obtained from males and females (19-39 years) at Prince of Songkla University, Thailand. A total of 64 strains of coagulase-positive and 85 strains of coagulase-negative staphylococci were collected. With each group, the specimens were classified as no treatment, antibiotic treatment, and other treatment. The samples were taken by swabbing acne lesions on the faces with sterile cotton swabs. The swabs were directly inoculated on mannitol salt agar (MSA, Merck, Darmstadt, Germany) and incubated at $35^{\circ} \mathrm{C}$ for $48 \mathrm{hr}$. A wellisolated colony was transferred to trypticase soy agar (TSA, Difco, Becton Dickinson, Sparks, MD, U.S.A.) and incubated at $35^{\circ} \mathrm{C}$ for $24 \mathrm{hr}$. Staphylococci were identified on the basis of colony characteristics, Gram stain, catalase test, and coagulase test. The cultures were stored at $4^{\circ} \mathrm{C}$ until use.

Antibiotic Susceptibility Testing — Antibiotic susceptibility testing was performed using disk diffusion method according to Clinical and Laboratory Standards Institute guidelines (CLSI). ${ }^{21)}$ Susceptibility of the isolated coagulasepositive and coagulase-negative staphylococci to a representative drug from different groups of antibiotics was determined. The antibiotics include $\beta$-lactam, glycopeptide, aminoglycoside, macrolide, tetracycline, quinolone, and miscellaneous group. Disks of ciprofloxacin $(5 \mu \mathrm{g})$, clindamycin $(2 \mu \mathrm{g})$, erythromycin $(15 \mu \mathrm{g})$, gentamicin $(10 \mu \mathrm{g})$, oxacillin $(1 \mu \mathrm{g})$, penicillin $(10$ units), teicoplanin $(30 \mu \mathrm{g})$, tetracycline $(30 \mu \mathrm{g})$, trimethoprim-sulfamethoxazole $\quad(1.25 / 23.75 \mu \mathrm{g})$, and vancomycin $(30 \mu \mathrm{g})$ were purchased from Oxoid, Basingstoke, Hamshire, England. S. aureus
ATCC 25923 was used as a control strain. The experiment was carried out in duplicate, inhibition zones were averaged and compared with the standard values to categorize whether it is susceptible or resistant. \% sensitivity was calculated from the numbers of the isolates which were sensitive over the total numbers of isolates tested $\times 100$. Statistical analysis was performed using one-way analysis of variance (ANOVA). Differences were considered significant at $p<0.05$.

Extract Preparation $-R$. tomentosa leaves were dried in oven at $60^{\circ} \mathrm{C}$ for $48 \mathrm{hr}$ and ground in an electrical blender. The powder was extracted with $95 \%$ ethanol and left at room temperature for 7 days. The extract was evaporated by using a rotary evaporator (BUCHI Rotavapor R-114, Büchi Rotavapor R-114, Büchi Labortechnik AG, Flawil, Switzerland) and kept at $4^{\circ} \mathrm{C}$.

Fractionation and Isolation - The dried ground leaves of $R$. tomentosa $(2.1 \mathrm{~kg})$ were sequentially extracted at room temperature with dichloromethane $\left(\mathrm{CH}_{2} \mathrm{Cl}_{2}\right)$ and acetone $\left(\mathrm{Me}_{2} \mathrm{CO}\right)$. The $\mathrm{Me}_{2} \mathrm{CO}$ extract $(46.6 \mathrm{~g}$ ) was further fractionated by dissolving in hexane $\left[\mathrm{CH}_{3}\left(\mathrm{CH}_{2}\right)_{4} \mathrm{CH}_{3}\right]$. The soluble fraction $(21.4 \mathrm{~g})$ was then separated on quick column chromatography (QCC) using silica gel $60 \mathrm{H}$ (Merck) and eluted with $\mathrm{CH}_{3}\left(\mathrm{CH}_{2}\right)_{4} \mathrm{CH}_{3}$ $\mathrm{CH}_{2} \mathrm{Cl}_{2}, \mathrm{CH}_{2} \mathrm{Cl}_{2}, \mathrm{CH}_{2} \mathrm{Cl}_{2}-\mathrm{Me}_{2} \mathrm{CO}$ and $\mathrm{Me}_{2} \mathrm{CO}$ gradient solvent system to give 20 fractions. Fraction $6(606.0 \mathrm{mg})$ was subjected to column chromatography (CC) using silica gel 100 (Merck) and eluted with $\mathrm{CH}_{2} \mathrm{Cl}_{2}$ and $\mathrm{CH}_{2} \mathrm{Cl}_{2}$-methanol $(\mathrm{MeOH})$ gradient to give fractions $6 \mathrm{~A}-6 \mathrm{G}$. Fraction 6C $(183.6 \mathrm{mg})$ was further fractionated by $\mathrm{CC}$ and eluted with $\mathrm{CH}_{2} \mathrm{Cl}_{2}$ to give fractions $6 \mathrm{C} 1-6 \mathrm{C} 6$. Fraction $6 \mathrm{C} 3(138.1 \mathrm{mg})$ was subjected to $\mathrm{CC}$, eluting with $\mathrm{CH}_{3}\left(\mathrm{CH}_{2}\right)_{4} \mathrm{CH}_{3}-\mathrm{Me}_{2} \mathrm{CO}$ (97:3) to give fractions $6 \mathrm{C} 3 \mathrm{~A}-6 \mathrm{C} 3 \mathrm{G}$. Bioassay-guided chromatography of this extract allowed the isolation of the active principal. Rhodomyrtone $(23.0 \mathrm{mg})$ was obtained from fraction $6 \mathrm{C} 3 \mathrm{~F}(31.4 \mathrm{mg})$ by crystallization from $\mathrm{CH}_{3}\left(\mathrm{CH}_{2}\right)_{4} \mathrm{CH}_{3}-\mathrm{Me}_{2} \mathrm{CO}$ (5:1). The structures of the compounds were characterized by extensive 1- and 2D NMR spectroscopy and mass spectroscopy.

Preliminary Test for Antibacterial Activity Antimicrobial activity was determined by agar disk diffusion method. ${ }^{21)}$ The ethanol extract was dissolved in dimethyl sulfoxide (DMSO, Sigma, Aldrich, Germany) and $10 \mu \mathrm{l}$ of the extract were loaded onto sterile filter paper disk (diameter $6 \mathrm{~mm}$ ). Three to five colonies of overnight culture 
on TSA were transferred to Mueller-Hinton Broth (MHB, Difco) and incubated for 4-5 hr. The bacterial suspension was adjusted to McFarland standard No. 0.5 and spreaded on Mueller-Hinton agar (MHA, Difco) plates. The disks were placed on the cultured plates and incubated at $35^{\circ} \mathrm{C}$ for $16-18 \mathrm{hr}$. The diameters of the inhibition zones $(\mathrm{mm})$ were measured and the mean was recorded.

Minimal Inhibitory Concentration (MIC) Determination — The MICs of antimicrobial agents were determined by a modified broth microdilution method in accordance with CLSI. ${ }^{22)}$ The extract $(20 \mu \mathrm{l})$ was diluted to final concentration ranging from $1024-0.5 \mu \mathrm{g} / \mathrm{ml}$ in 96-well microtitre plate and $80 \mu \mathrm{l}$ of MHB were added. One hundred microliter of the bacterial suspension $\left(10^{6}\right.$ colony forming unit, $\mathrm{CFU} / \mathrm{ml}$ ) were inoculated and incubated at $35^{\circ} \mathrm{C}$ for $16-18 \mathrm{hr}$. The MIC was defined as the lowest concentration completely inhibit the bacterial growth. Penicillin and most commonly used antibiotics for acnes including clindamycin and erythromycin were determined. In addition, vancomycin, an effective drug for methicillin-resistant $S$. aureus was included. Experiments were done in triplicate.

Time-Kill Study — Time-kill kinetic experiments of the extract were performed in trypticase soy broth (TSB, Difco). An inoculum of $10^{6} \mathrm{CFU} / \mathrm{ml}$ of growing cultures was added to the medium supplemented with $0.5,1,2$, and 4 MIC of the extract and incubated at $35^{\circ} \mathrm{C}$. Extract-free inoculated medium was used as growth control. Viability counts were performed at $0,2,4,6,8,12,16$, 20 , and $24 \mathrm{hr}$. The experiment was carried out in duplicate and a graph was plotted in log number of the organisms. The results were presented as mean \pm standard error.

\section{RESULTS}

Antibiotic susceptibility profiles of coagulasepositive and coagulase-negative staphylococci are shown in Fig. 1. The patterns between the two groups were very similar. Approximately $60-80 \%$ of the isolates were demonstrated to resist to penicillin. Relatively, high numbers of them (40-90\%) were resistant to clindamycin and erythromycin. For coagulase-positive staphylococci (Fig. 1A), all isolates in all groups were susceptible to gentamicin. Almost $100 \%$ of the isolates were susceptible to vancomycin and teicoplanin. At least $80 \%$ of the
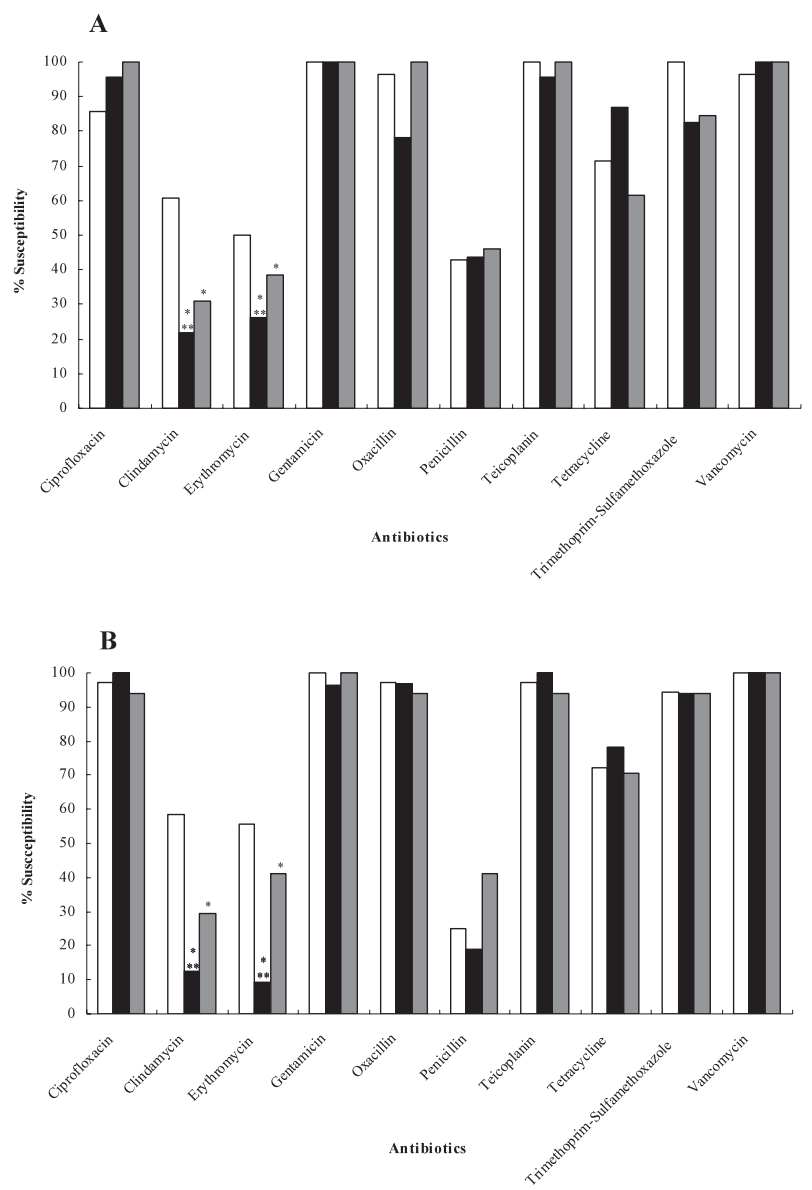

Fig. 1. Antibiotic Susceptibility Profiles

Coagulase-positive staphylococci, $n=64$ (A) and coagulasenegative staphylococci, $n=85$ (B). White bars represent isolates from non-treated subjects ( $n=28$ for coagulase-positive, $n=36$ for coagulase-negative), black bars represent antibiotic-treated subjects ( $n=13$ for coagulase-positive, $n=17$ for coagulase-negative), gray bars represent subjects with other treatments $(n=23$ for coagulasepositive, $n=32$ for coagulase-negative). ${ }^{*}$ and ${ }^{* *}$ values are significantly different from no treatment group and other treatment group, respectively $(p<0.05)$.

isolates were susceptible to ciprofloxacin, oxacillin, and trimethoprim-sulfamethoxazole and $60 \%$ were susceptible to tetracycline. For coagulase-negative staphylococci (Fig. 1B), 100\% of the isolates from different groups of subjects were susceptible to vancomycin. With gentamicin, $100 \%$ of the isolates from no treatment group and subjects with other treatments were susceptible while $96.4 \%$ from antibiotic-treated subjects were susceptible to this antibiotic. More than $90 \%$ of the isolates were susceptible to ciprofloxacin, oxacillin, teicoplanin, and trimethoprim-sulfamethoxazole. Only $70 \%$ of the isolates were susceptible to tetracycline. Interestingly, it has been demonstrated that the isolates from antibiotic-treated patients were less susceptible to 
clindamycin and erythromycin than those from the untreated and other treatment groups $(p<0.05)$.

The ethanol extract of $R$. tomentosa was demonstrated to possess antibacterial activity against all tested isolates. The inhibition zones of $82.8 \%$ of the coagulase-positive and $87 \%$ coagulase-negative staphylococci were from 11-15 mm (Table 1). The average inhibition zones of coagulase-positive and coagulase-negative staphylococci were $12.1 \pm$ $1.80 \mathrm{~mm}$ and $14 \pm 1.67 \mathrm{~mm}$, respectively. The inhibition zone of $S$. aureus ATCC 25923 was $11 \mathrm{~mm}$.

The MICs of the ethanol extract of $R$. tomentosa and most commonly employed antibiotics against staphylococci are given in Table 2. The MIC values of the extract ranged from 32-1024 $\mu \mathrm{g} / \mathrm{ml}$. $\mathrm{MIC}_{50}$ and $\mathrm{MIC}_{90}$ values for coagulase-positive staphylococci were 64 and $512 \mu \mathrm{g} / \mathrm{ml}$, respectively. Similarly, coagulase-negative staphylococci demonstrated the $\mathrm{MIC}_{50}$ and $\mathrm{MIC}_{90}$ at 64 and $256 \mu \mathrm{g} / \mathrm{ml}$, respectively. The MIC value of $R$. tomentosa extract against $S$. aureus ATCC 25923 was $32 \mu \mathrm{g} / \mathrm{ml}$ highlighted the potential use of rhodomyrtone, a pure compound isolated from $R$. tomentosa, against this organism. Further study the MIC of rhodomyrtone was $0.5 \mu \mathrm{g} / \mathrm{ml}$ which was similar to that of vancomycin. $\mathrm{MICs}_{50}$ of clindamycin for coagulase-

Table 1. Antibacterial Activity of the Ethanol Extract of $R$. tomentosa on Coagulase-positive and Coagulasenegative Staphylococci Isolated from Acne Lesions

\begin{tabular}{lcc}
\hline \hline \multirow{2}{*}{$\begin{array}{l}\text { Inhibition zone } \\
(\mathrm{mm})\end{array}$} & \multicolumn{2}{c}{ Numbers of isolates $(\%)$} \\
\cline { 2 - 3 } & $\begin{array}{c}\text { coagulase-positive } \\
(n=64)\end{array}$ & $\begin{array}{c}\text { coagulase negative } \\
(n=85)\end{array}$ \\
\hline$\leq 10$ & 14.1 & 1.2 \\
$11-15$ & 82.8 & 87.0 \\
$16-20$ & 3.1 & 11.8 \\
\hline \multicolumn{2}{c}{ S. aureus ATCC 25923: Inhibition zone was $11.0 \mathrm{~mm}}$.
\end{tabular}

positive and coagulase-negative staphylococci were 32 and $512 \mu \mathrm{g} / \mathrm{ml}$, respectively. For erythromycin, $\mathrm{MICs}_{50}$ were $64 \mu \mathrm{g} / \mathrm{ml}$ and $128 \mu \mathrm{g} / \mathrm{ml}$ for coagulasepositive and coagulase-negative staphylococci, respectively. MICs $_{90}$ were higher than $1024 \mu \mathrm{g} / \mathrm{ml}$ for clindamycin and erythromycin in both groups of staphylococci. For penicillin, $\mathrm{MIC}_{50}$ and $\mathrm{MIC}_{90}$ were $0.5 \mu \mathrm{g} / \mathrm{ml}$ and $16 \mu \mathrm{g} / \mathrm{ml}$ for coagulase-positive staphylococci. Similarly, the $\mathrm{MIC}_{50}$ and $\mathrm{MIC}_{90}$ for coagulase-negative staphylococci were $1 \mu \mathrm{g} / \mathrm{ml}$ and $8 \mu \mathrm{g} / \mathrm{ml}$, respectively. $\mathrm{MIC}_{50}$ and $\mathrm{MIC}_{90}$ were below the breakpoint for vancomycin but higher than the breakpoints for clindamycin, erythromycin, and penicillin. This indicated that vancomycin was the only drug that effective against all of the tested staphylococcal isolates.

Time-kill study was carried out with ten randomly selected isolates from coagulase-positive staphylococci and coagulase-negative group. Patterns of cell survival after treatment were similar among different isolates. A representative strain from each group and S. aureus ATCC 25923 were presented in Fig. 2. The numbers of viable cells of coagulase-positive staphylococci after exposure to $4 \mathrm{MIC}$ of the extract decreased at least $3 \mathrm{log}$ fold within $6-8 \mathrm{hr}$ (Fig. 2A). The time-kill curves of coagulase-negative staphylococci were similar to coagulase-positive staphylococci. At $4 \mathrm{MIC}$, the level of tested isolates decreased by $3 \log$ fold within $6 \mathrm{hr}$ (Fig. 2B). For $S$. aureus ATCC 25923, the numbers of viable cells also reduced $3 \log$ fold within $6 \mathrm{hr}$ after treating with 4 MIC of the extract (Fig. 2C).

Table 2. $\mathrm{MIC}_{50}$ and $\mathrm{MIC}_{90}$ of the Ethanol Extract of $R$. tomentosa, Clindamycin, Erythromycin, Penicillin, and Vancomycin against Coagulase-positive and Coagulase-negative Staphylococci Isolated from Acne Lesions

\begin{tabular}{|c|c|c|c|c|c|c|c|c|c|c|}
\hline \multirow[t]{2}{*}{ Antibacterial agents } & \multicolumn{2}{|c|}{$\begin{array}{c}\text { coagulase-positive } \\
\text { staphylococci }(n=64)\end{array}$} & \multicolumn{2}{|c|}{$\begin{array}{c}\text { coagulase-negative } \\
\text { staphylococci }(n=85)\end{array}$} & \multirow{2}{*}{\multicolumn{2}{|c|}{$\begin{array}{c}\text { MIC ranges } \\
(\mu \mathrm{g} / \mathrm{ml})\end{array}$}} & \multirow{2}{*}{\multicolumn{2}{|c|}{$\begin{array}{c}\text { MBC ranges } \\
(\mu \mathrm{g} / \mathrm{ml})\end{array}$}} & \multicolumn{2}{|c|}{ MIC breakpoints $(\mu \mathrm{g} / \mathrm{ml})$} \\
\hline & $\begin{array}{c}\mathrm{MIC}_{50} \\
(\mu \mathrm{g} / \mathrm{ml})\end{array}$ & $\begin{array}{l}\mathrm{MIC}_{90} \\
(\mu \mathrm{g} / \mathrm{ml})\end{array}$ & $\begin{array}{l}\mathrm{MIC}_{50} \\
(\mu \mathrm{g} / \mathrm{ml})\end{array}$ & $\begin{array}{l}\mathrm{MIC}_{90} \\
(\mu \mathrm{g} / \mathrm{ml})\end{array}$ & & & & & Susceptible & Resistant \\
\hline R. tomentosa extract & 64 & 512 & 64 & 256 & 32 & -1024 & 32 & $>1024$ & - & - \\
\hline Clindamycin & 32 & $>1024$ & 512 & $>1024$ & 8 & $->1024$ & 8 & $>1024$ & $\leq 0.5$ & $\geq 4$ \\
\hline Erythromycin & 64 & $>1024$ & 128 & $>1024$ & & $50->1024$ & 1 & $>1024$ & $\leq 0.5$ & $\geq 8$ \\
\hline Penicillin & 0.5 & 16 & 1 & 8 & & $06-$ & $0.06-$ & 64 & $\leq 0.12$ & $\geq 0.25$ \\
\hline Vancomycin & 1 & 1 & 1 & 2 & & $25-$ & $0.25-$ & 4 & $\leq 4$ & $\geq 32$ \\
\hline
\end{tabular}

S. aureus ATCC 25923: MICs of $R$. tomentosa extract and rhodomyrtone were 32 and $0.5(\mu \mathrm{g} / \mathrm{ml})$, respectively. 

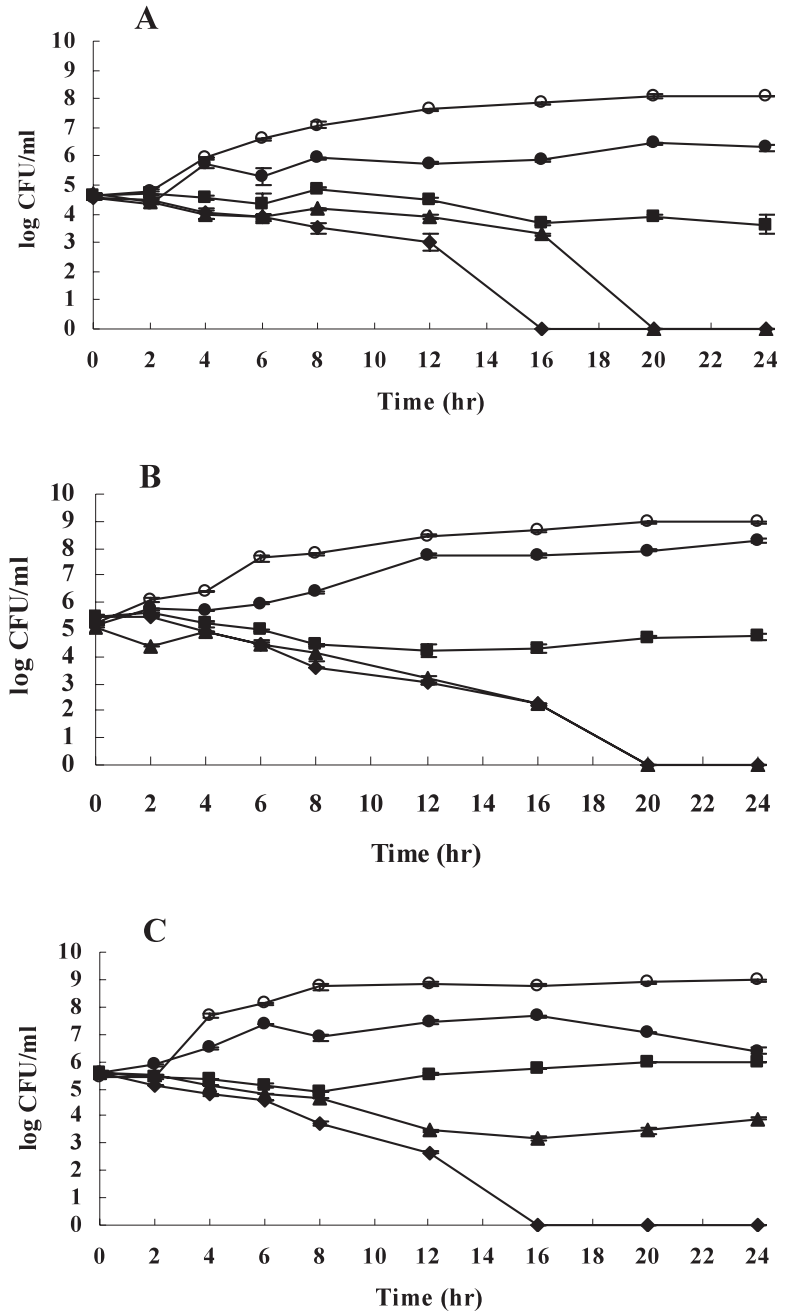

Fig. 2. Time-kill Curves of Representative Isolates of Staphylococci

Coagulase-negative staphylococci NPRC 302, MIC $=64 \mu \mathrm{g} / \mathrm{ml}$ (A), coagulase-negative staphylococci NPRC 502, $\mathrm{MIC}=32 \mu \mathrm{g} / \mathrm{ml}$ (B), and $S$. aureus ATCC 25923, MIC $=32 \mu \mathrm{g} / \mathrm{ml}$ (C). The closed circles $(\bullet)$, squares $(\boldsymbol{\bullet})$, triangles $(\boldsymbol{\Lambda})$, and rhombuses $(\bullet)$ indicate viable numbers of the isolates treated with the extract at $0.5 \mathrm{MIC}$, MIC, $2 \mathrm{MIC}$ and $4 \mathrm{MIC}$, respectively. The open circles $(\bigcirc)$ represent viable numbers of the isolates in control suspension. The level of detection limit was 100 $\mathrm{CFU} / \mathrm{ml}$.

\section{DISCUSSION}

The evidence of resistance of numerous pathogens to antimicrobial agents is of public health concern. Recently, several studies have shown that the staphylococci have started to gain resistance to many widely used antibiotics including $\beta$-lactams, glycopeptides, aminoglycosides, macrolides, tetracycline, quinolone, and miscellaneous group. ${ }^{10,23,24)}$ In the present study, the resistance of staphylococci was found in most groups of antibiotics, especially clindamycin, erythromycin, and penicillin. Previous studies have also reported resistance of coagulasenegative staphylococci and S. aureus against clindamycin and erythromycin. $9,10,25)$ Our results indicated that the isolates from the antibiotic-treated subjects were less susceptible to clindamycin and erythromycin (commonly used topical antibiotics for acne treatment) than those from the untreated subjects. Similar reports were also documented. After 12 weeks of treatment with erythromycin, S. epidermidis was found to become completely resistant and there was an increase in resistance to clindamycin and tetracycline. ${ }^{26)}$ After long-term systemic antibiotic therapy, the resistant strains of S. epidermidis increased. ${ }^{10)}$ The prevalence of erythromycin-resistant coagulase-negative staphylococci increased to $98 \%$ by week $12 .{ }^{11)}$ Contrary to those for clindamycin and erythromycin, \% susceptibility of coagulase-negative staphylococci to penicillin seemed to be higher in the subjects with other treatments, compared to the other groups (Fig. 1B). This is probably due to the fact that these subjects did not use antibiotics for treating their acnes. They used hormones, chemicals, or other conventional medicines. Therefore, their sensitivity to penicillin could be at any level.

Due to the appearance of increasing in antibiotic resistance, many researcher have investigated alternative approaches to treat staphylococcal infection. Natural products including plant extracts have been extensively studied. Plant compounds are directly antibacterial agents (cidal or static). Gibbons (2004) ${ }^{27)}$ classed anti-staphylococcal plant natural products into different categories: monoterpenes, sesquiterpenes, diterpenes, triterpenes, phenylpropanoids and stilbenoids, simple phenols and tropolones, flavonoids, alkaloids, polyketides and polyynes, sulfur containing products, and acylphloroglucinols. Very limited investigations have been carried out on $R$. tomentosa. The ethyl acetate extract of the leaves of $R$. tomentosa yielded rhodomyrtone which is in the class of acylphloroglucinols. It has been claimed to possess antibacterial activity against Escherichia coli and S. aureus without supporting data. ${ }^{19)}$ The acylphloroglucinols are natural products based on aromatic ring that in many cases has been reduced or has keto-enol form. The majority of these products are prenylated and/or farnesylated and possess simple acyl groups. ${ }^{27)}$ Previously, hyperforin isolated from Hypericum perforatum was reported to exhibit excellent effect against penicillin-resistant and methicillin-resistant $S$. aureus and $S$. aureus 
ATCC 25923 with the MIC $0.1-1 \mu \mathrm{g} / \mathrm{ml}^{28,29)}$ Our results clearly indicated that rhodomyrtone was highly effective against $S$. aureus ATCC 25923 with the MIC value at $0.5 \mu \mathrm{g} / \mathrm{ml}$ which is very closed to that of vancomycin which is the effective agent at present. In addition, it demonstrated the same effect on clinical isolates (data not shown). This finding challenges the use of rhodomyrtone as an alternative agent against staphylococcal infections. Preliminary experiment on certain important enzymes such as lipase and protease demonstrated no effect. Other effects on antibacterial mechanisms such as biofilm formation, quorum sensing, cell surface hydrophobicity, etc. should be thoroughly investigated for drug development.

Acknowledgements This work was supported by the Thailand Research Fund: Basic Research Grant (DBG 5180021), Fiscal year 2008-2011 and Research Assistantship, Faculty of Science, Prince of Songkla University, Thailand.

\section{REFERENCES}

1) Iwatsuki, K., Yamasaki, O., Morizane, S. and Oono, T. (2006) Staphylococcal cutaneous infections: invasion, evasion and aggression. J. Dermatol. Sci., 42, 203-214.

2) Brook, I., Frazier, E. H., Cox, M. E. and Yeager, J. K. (1995) The aerobic and anaerobic microbiology of pustular acne lesions. Anaerobe., 1, 305-307.

3) O'Leary, W. M. and Weld, J. T. (1964) Lipolytic Activities of Staphylococcus aureus. I. Nature of the enzyme producing free fatty acids from plasma lipids. J. Bacteriol., 88, 1356-1363.

4) Reisner, R. M. and Puhvel, M. (1969) Lipolytic activity of Staphylococcus albus. J. Invest. Dermatol., 53, 1-7.

5) Longshaw, C. M., Farrell, A. M., Wright, J. D. and Holland, K. T. (2000) Identification of a second lipase gene, gehD, in Staphylococcus epidermidis: comparison of sequence with those of other staphylococcal lipases. Microbiology, 146, 1419-1427.

6) Purvis, D., Robinson, E., Merry, S. and Watson, P. (2006) Acne, anxiety, depression and suicide in teenagers: a cross-sectional survey of New Zealand secondary school students. $J$. Paediatr. Child Health, 42, 793-796.

7) Stern, R. S. (2000) Medication and medical service utilization for acne 1995-1998. J. Am. Acad. Dermatol., 43, 1042-1048.
8) Vowels, B. R., Feingold, D. S., Sloughfy, C., Foglia, A. N., Konnikov, N., Ordoukhanian, E., Starkey, P. and Leyden, J. J. (1996) Effects of topical erythromycin on ecology of aerobic cutaneous bacterial flora. Antimicrob. Agents Chemother., 40, 25982604.

9) Cove, J. H., Eady, E. A. and Cunliffe, W. J. (1990) Skin carriage of antibiotic-resistant coagulasenegative staphylococci in untreated subjects. J. Antimicrob. Chemother, 25, 459-469.

10) Nishijima, S., Kurokawa, I., Katoh, N. and Watanabe, K. (2000) The bacteriology of acne vulgaris and antimicrobial susceptibility of Propionibacterium acnes and Staphylococcus epidermidis isolated from acne lesions. J. Dermatol., 27, 318323.

11) Mills, O., Jr., Thornsberry, C., Cardin, C. W., Smiles, K. A. and Leyden, J. J. (2002) Bacterial resistance and therapeutic outcome following three months of topical acne therapy with $2 \%$ erythromycin gel versus its vehicle. Acta Derm. Venereol., 82, 260-265.

12) Voravuthikunchai, S. P. and Kitpipit, L. (2005) Effective medicinal plant extracts against hospital strains of methicillin-resistant Staphylococcus aureus. Clin. Microbiol. Infect., 11, 510-512.

13) Salari, M. H., Amine, G., Shirazi, M. H., Hafezi, R. and Mohammadypour, M. (2006) Antibacterial effects of Eucalyptus globulus leaf extract on pathogenic bacteria isolated from specimens of patients with respiratory tract disorders. Clin. Microbiol. Infect., 12, 194-196.

14) Carson, C. F., Mee, B. J. and Riley, T. V. (2002) Mechanism of action of Melaleuca alternifolia (tea tree) oil on Staphylococcus aureus determined by time-kill, lysis, leakage, and salt tolerance assays and electron microscopy. Antimicrob. Agents Chemother., 46, 1914-1920.

15) Djipa, C. D., Delmee, M. and Quetin-Leclercq, J. (2000) Antimicrobial activity of bark extracts of Syzygium jambos (L.) alston (Myrtaceae). J. Ethnopharmacol., 71, 307-313.

16) Abu-Shanab, B., Adwan, G., Abu-Safiya, D., Jarrar, N. and Adwan, K. (2004) Antibacterial activities of some plant extracts utilized in popular medicine in Palestine. Turkish Journal of Biology, 28, 99-102.

17) Babayi, H., Kolo, I., Okogun, J. I. and Ijah, U. J. J. (2004) The antimicrobial activities of methanolic extracts of Eucalyptus camaldulensis and Terminalia catappa against some pathogenic microorganisms. Biokemistri, 16, 106-111.

18) Gomber, C. and Saxena, S. (2007) Antistaphylococcal potential of Callistemon rigidus. 
Central European Journal of Medicine, 2, 79-88.

19) Salni, D., Sargent, M. V., Skelton, B. W., Soediro, I., Sutisna, M., White, A. H. and Yulinah, E. (2002) Rhodomyrtone, an antibiotic from Rhodomyrtus tomentosa. Aust. J. Chem., 55, 229-232.

20) Voravuthikunchai, S. P., Limsuwan, S. and Chusri, S. (2007) New perspectives on herbal medicines for bacterial infections. In Recent Progress in Medicinal Plants, Vol.18: Natural Products II (Govil, G. N., Singh, V. K. and Siddqui, T., Eds.), Studium Press, LLC, Houston, Texas, U.S.A., pp. 41-101.

21) Clinical and Laboratory Standards Institute (2006a) Performance Standards for Antimicrobial Disk Susceptibility Tests; Approved Standard, 9th ed., CLSI Document M2-A9. Clinical and Laboratory Standards Institute, Wayne, PA, U.S.A.

22) Clinical and Laboratory Standards Institute (2006b) Methods for Dilution Antimicrobial Susceptibility Tests for Bacteria that Grow Aerobically; Approved Standard, 7th ed., CLSI Document M7-A7. Clinical and Laboratory Standards Institute, Wayne, PA, U.S.A.

23) Hoeger, P. H. (2004) Antimicrobial susceptibility of skin-colonizing $S$. aureus strains in children with atopic dermatitis. Pediatr. Allergy Immunol., 15, 474-477.

24) Brown, P. D. and Ngeno, C. (2007) Antimicrobial resistance in clinical isolates of Staphylococcus aureus from hospital and community sources in southern Jamaica. Int. J. Infect. Dis., 11, 220-225.

25) Kim, H. B., Jang, H. C., Nam, H. J., Lee, Y. S., Kim, B. S., Park, W. B., Lee, K. D., Choi, Y. J., Park, S. W., Oh, M. D., Kim, E. C. and Choe, K. W. (2004) In vitro activities of 28 antimicrobial agents against Staphylococcus aureus isolates from tertiary-care hospitals in Korea: a nationwide survey. Antimicrob. Agents Chemother, 48, 1124-1127.

26) Harkaway, K. S., McGinley, K. J., Foglia, A. N., Lee, W. L., Fried, F., Shalita, A. R. and Leyden, J. J. (1992) Antibiotic resistance patterns in coagulasenegative staphylococci after treatment with topical erythromycin, benzoyl peroxide, and combination therapy. Br. J. Dermatol., 126, 586-590.

27) Gibbons, S. (2004) Anti-staphylococcal plant natural products. Nat. Prod. Rep., 21, 263-277.

28) Schempp, C. M., Pelz, K., Wittmer, A., Schopf, E. and Simon, J. C. (1999) Antibacterial activity of hyperforin from St John's wort, against multiresistant Staphylococcus aureus and gram-positive bacteria. Lancet, 353, 2129.

29) Reichling, J., Weseler, A. and Saller, R. (2001) A current review of the antimicrobial activity of Hypericum perforatum L. Pharmacopsychiatry, 34, Suppl. 1, S116-S118. 